\title{
БУХГАЛТЕРСКИЙ УЧЕТ ОПЕРАЦИЙ ПО ИМПОРТУ НА ОСНОВЕ РИСК-ОРИЕНТИРОВАННОГО ПОДХОДА И ЕГО СТАНДАРТИЗАЦИЯ
}

\author{
(c) 2020 Листопад Е. Е. \\ кандидат экономических наук, доцент, Департамент учета, анализа и аудита \\ Финансовый университет при Правительстве Российской Федерации, Россия, Москва \\ E-mail: eelistopad@fa.ru
}

В предлагаемой предложена и раскрыта возможность стандартизации операций по импорту на основе риск-ориентированного подхода, выделены стимулы и препятствия отражения информации о рисках, приведены преимущества стандартизации учетной информации.

Ключевые слова: риск-ориентированный подход, операции по импорту, внутрифирменные стандарты учета, стандартизация операций.

В современном мире находясь в изоляции от других стран, ни одно государство не может нормально функционировать и динамично развиваться. Формой экономического сотрудничества России с иностранными государствами является внешнеторговая деятельность, которая выражается в виде экспортно-импортных операций.

Вследствие различий в правовых системах, особенностей валютного регулирования, а также обычаях делового оборота возникают специфические, присущие операциям по импорту особенности. Операции по импорту представляют собой обособленный комплекс экономических отношений, характеризующийся самостоятельностью, целостностью, спецификой регулирования, имеющий собственный понятийный аппарат, а также порождают специальный бухгалтерский методологический инструментарий, присущий только указанным отношениям.

Риск является неотъемлемой частью любой хозяйственной деятельности, играет все большую роль в управлении хозяйствующего субъекта. Игнорирование риска ведет к неэффективному функционированию организации, потери конкурентоспособности и, в конечном счете, к банкротству. Новые условия организации и ведения бизнеса требуют не только внедрения принципиально иных способов хозяйствования, но и изменения взглядов на сущность и содержание основных функций, выполняемых специалистами учетно-аналитических отделов организации для обеспечения ритмичной и рентабельной ее работы.

Для целенаправленного и эффективного воздействия на бизнес-процессы организации необходима разработка и создание новой модели учета операций по импорту, основанной на жестко структурированной формализованной системе бухгалтерского учета с внутренними правилами подготовки и формирования отчетных данных, базирующейся на определенной унификации и стандартизации правил ведения бухгалтерского учета импортных операций, процедур обработки и анализа учетной информации.

Риск это термин, который часто употребляется в обычной повседневной жизни, а также в экономической литературе и в хозяйственной деятельности предприятий и организаций. Это понятие включает различные и порой противоположные смысловые нагрузки.

Остановимся на самых известных точках зрения трактовки понятия «риск». 1 точка зрения - изучение риска с финансовой точки зрения, а именно, финансовых потерь для человека, организации или государства $[2,7,8]$.

2 точка зрения - изучение риска с помощью инструментария теории вероятности. Авторы данной позиции определяют любой риск как функцию, которая является результатом вероятности наступления убытка и его величины $[3,5,12,14]$.

3 точка зрения - изучение риска на микроуровне, а именно: как деятельность хозяйствующего субъекта в определенной внешней среде, то есть в условии ее неопределенности $[1,9,10]$.

4 точка зрения - изучение риска как неразрывной взаимосвязи его и прибыли $[15,16,17]$.

При проведении на уровне фирмы внешнеэкономической деятельности, и в частности 
импортных операций предрасположенность рискам увеличивается, так как на деятельность организации начинают оказывать влияние не только внутренние риски, присущие каждой стране, но и риски, присущие мировым экономическим системам.

Для отражения операций по импорту на основе риск-ориентированного подхода требуется создание согласованной и нераздельной системы стандартизации, которая будет включать в себя и функции контроля деятельности всех структурных подразделений, связанных с импортом.

Нормативное регулирование бухгалтерского учета в России классифицируется по пяти уровням, что представлено на рис. 1.

В научной и практической литературе выделяют два подхода к формированию учетной системы экономического субъекта и взаимодействованию ее элементов.

Сторонниками первого подхода являются Я.В.Соколов, В.Д.Новодворский. Суть данного подхода заключается в том, что учетная политика - это структурообразующая основа системы бухгалтерского учета организации. Так, проф. Я.В.Соколов писал: «В жизни проявляются результаты, которые с одной стороны мы создаем своим трудом, физическим и умственным, с другой - финансовый результат - это следствие той изворотливости ума, которой Бог одарил нас. Выбирая учетную политику, мы предопределяем финансовый результат» [13].

Второй подход базируется на создании от- дельной системы взаимосвязанных, а может быть и взаимоподчиненных внутренних стандартов. Учетной политике при втором подходе отводится роль одного из множества внутренних документов. Таким образом, перед нами порядок, представляющий систему стандартизации ведения бухгалтерского учета, а также подготовки на ее основе отчетных данных на основе использования профессионального суждения, основанного на применении требований и допущений бухгалтерского учета.

Стандарты, регламенты и положения организации как совокупность правил управления, направленных на достижение целей и задач реализации системного подхода к управлению, должны соответствовать особенностям регулирования внешнеэкономической деятельности. Основное назначение стандартов бухгалтерского учета в процессе разработки внутренних стандартов и регламентов состоит в том, чтобы раскрыть особенности операций по импорту конкретной организации.

Как национальным, так и международным стандартам свойственны недостатки. Основным недостатками можно считать отсутствие охвата всех аспектов учета; формулирование принципов учета в самом обобщенном виде; содержание многовариантных положений, зачастую противоречащих друг другу; не учитывают специфики хозяйственной деятельности организаций.

Поэтому считаем, что совокупность коррелирующих внутренних стандартов и регламен-

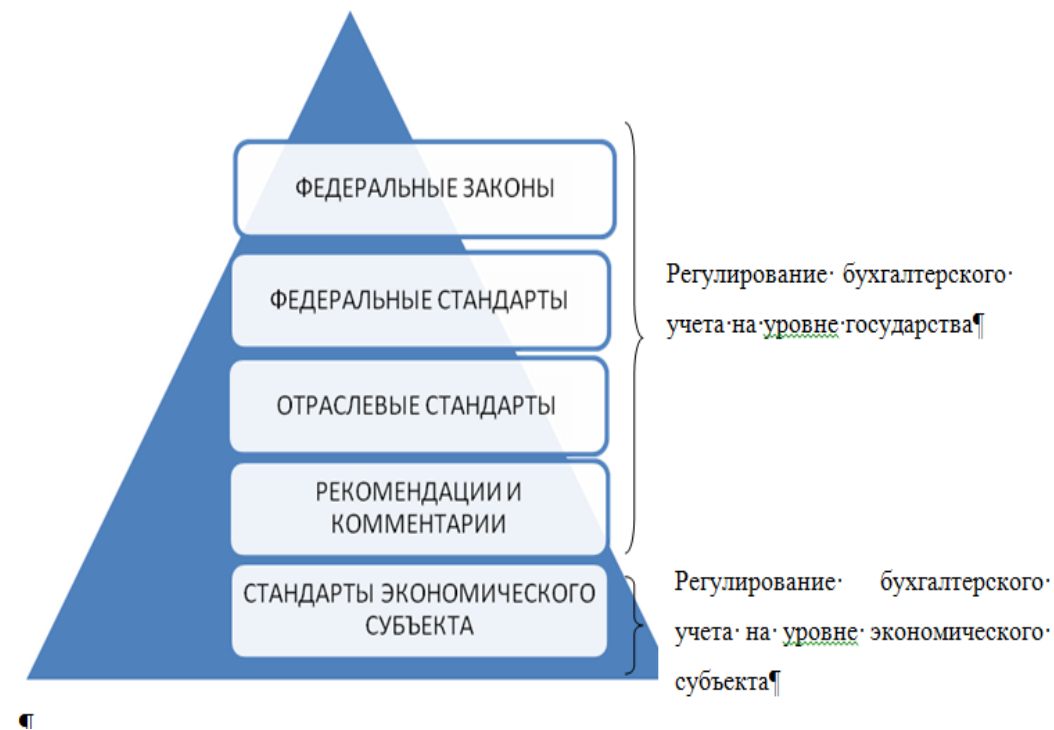

Puc. 1. Нормативное регулирование бухгалтерского учета внешнеэкономической деятельности в Российской Федерации 
тов должен включать в себя все аспекты процесса бухгалтерского учета - организационный аспект, методический и технический. В связи с этим можно сформулировать основную цель и задачи стандартизации и регламентации бухгалтерского учета операций по импорту. Так, цель стандартизации - это установить нормы, правила и требования, предъявляемые к учету операций по импорту для обеспечения соблюдения требований законодательства всех уровней. К задачам можно отнести:

1. установить нормы, правила и требования к учету рисков, которым подвержена организация на всех этапах осуществления операций по импорту;

2. формировать единые правила, регулирующие осуществление операций по импорту в условиях риск-ориентированного подхода;

3. разработать единые правила, регулирующие отражение в бухгалтерском учете организации-импортера рисков утраты и случайной гибели.

По нашему мнению, создание комплексных внутренних стандартов и регламентов повлечет усиление системы внутреннего контроля, а именно: позволит организации предотвращать возможные потери путем создания резервов; будет способствовать повышению эффективности работы с помощью создание единых принципов учета и оценки рисков, что приведет к усилению контрольной функции. Внутренние стандарты и регламенты организации представляют собой набор взаимосвязанных документов, регламентирующих как учетные, так и финансовые, юридические и управленческие процедуры. Предложенная иерархия внутренних стандартов сгруппирована в таблице 2 .

Стандартизация бухгалтерского учета операций по импорту представляет собой единую систему (рис. 2).

Внутренние регламенты осуществления фактов хозяйственной жизни по импорту должны утверждаться руководителем. В организационной части единой системы стандартов утверждается регламент, предлагаемая форма которого представлена в таблице 2 и 3.

Таблица 1. Иерархия внутренних стандартов

\begin{tabular}{|c|l|l|}
\hline Уровни & \multicolumn{1}{|c|}{ Наименование } & \multicolumn{1}{|c|}{ Набор документов } \\
\hline I & Организационный & $\begin{array}{l}\text { Регламент, утвержденный на уровне организации, который уста- } \\
\text { навливает однообразную методику к формированию информации о } \\
\text { наличии, состоянии и движении импортных активов путем учета всех } \\
\text { фактов хозяйственной жизни. }\end{array}$ \\
\hline II & Методический & $\begin{array}{l}\text { Методические указания (стандарты) и корреспонденция счетов с уче- } \\
\text { том специфики внешнеэкономической деятельности, основанной на } \\
\text { риск-ориентированном подходе («дерево» проводок) }\end{array}$ \\
\hline III & Технический & $\begin{array}{l}\text { Алгоритм составления форм отчетности и инструкци по ее формиро- } \\
\text { ванию }\end{array}$ \\
\hline
\end{tabular}

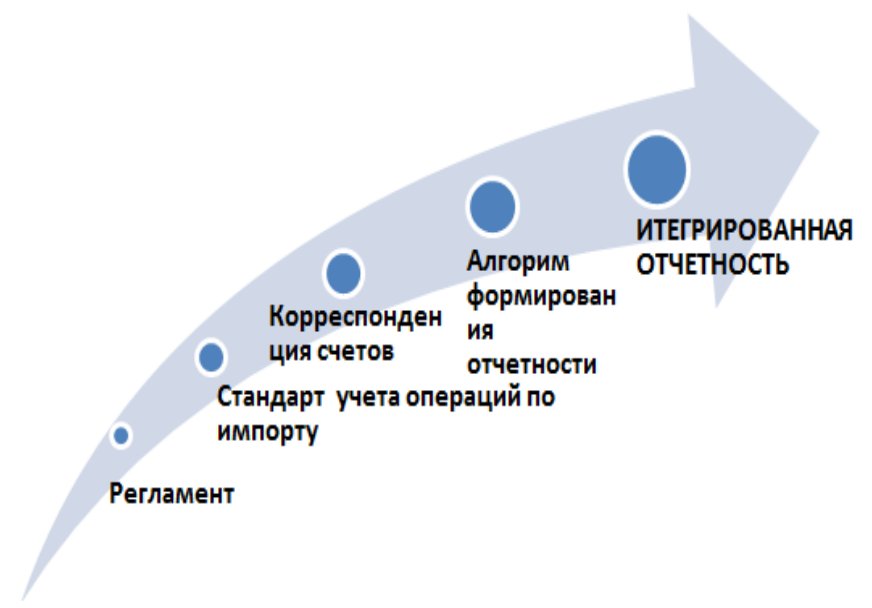

Puc. 2. Единая система стандартизации операций по импорту на основе риск-ориентированного подхода 
Таблица 2. Форма регламента по учету импортных объектов в части входящей информации

\begin{tabular}{|c|c|c|c|c|c|}
\hline $\begin{array}{l}\text { № } \\
\Pi / \Pi\end{array}$ & $\begin{array}{c}\text { Наименование } \\
\text { функции и ее со- } \\
\text { держание }\end{array}$ & $\begin{array}{c}\text { Ответственные за } \\
\text { исполнение }\end{array}$ & $\begin{array}{c}\text { Наименование } \\
\text { документа }\end{array}$ & От кого поступает & $\begin{array}{c}\text { Информационная } \\
\text { среда }\end{array}$ \\
\hline 1 & $\begin{array}{c}\text { Заключение им- } \\
\text { портного контрак- } \\
\text { та на закупку МПЗ. }\end{array}$ & $\begin{array}{c}\text { отдел по междуна- } \\
\text { родным отноше- } \\
\text { ниям, ответствен- } \\
\text { ное подразделение }\end{array}$ & $\begin{array}{l}\text { план закупки, } \\
\text { Заявка. }\end{array}$ & $\begin{array}{c}\text { ответственное } \\
\text { лицо подразделе- } \\
\text { ния }\end{array}$ & $\begin{array}{c}\text { бумажные носи- } \\
\text { тели. }\end{array}$ \\
\hline 2 & $\begin{array}{l}\text { Согласование про- } \\
\text { екта импортного } \\
\text { Контракта. }\end{array}$ & $\begin{array}{l}\text { эксперты соответ- } \\
\text { ствующих отделов }\end{array}$ & $\begin{array}{l}\text { проект импортно- } \\
\text { го контракта }\end{array}$ & $\begin{array}{l}\text { ответственное } \\
\text { лицо подразделе- } \\
\text { ния Выбранный } \\
\text { круг экспертов } \\
\text { указывается в ли- } \\
\text { сте согласования. }\end{array}$ & $\begin{array}{l}\text { бумажные носи- } \\
\text { тели }\end{array}$ \\
\hline 3 & $\begin{array}{l}\text { Анализ проекта } \\
\text { импортного кон- } \\
\text { тракта, выявление } \\
\text { и оценка рисков, } \\
\text { присущих опера- } \\
\text { циям по данному } \\
\text { контракту. }\end{array}$ & $\begin{array}{l}\text { эксперт службы по } \\
\text { защите интересов } \\
\text { Организации }\end{array}$ & $\begin{array}{l}\text { проект импортно- } \\
\text { го контракта / лист } \\
\text { согласования. }\end{array}$ & $\begin{array}{l}\text { ответственное } \\
\text { лицо подразделе- } \\
\text { ния }\end{array}$ & $\begin{array}{l}\text { бумажные носи- } \\
\text { тели }\end{array}$ \\
\hline 4 & $\begin{array}{l}\text { Анализ проекта } \\
\text { импортного кон- } \\
\text { тракта, выявление } \\
\text { и оценка рисков, } \\
\text { присущих опера- } \\
\text { циям по данному } \\
\text { контракту. }\end{array}$ & $\begin{array}{l}\text { финансовый ди- } \\
\text { ректор }\end{array}$ & $\begin{array}{l}\text { проект импортно- } \\
\text { го контракта / лист } \\
\text { согласования. }\end{array}$ & $\begin{array}{l}\text { ответственное } \\
\text { лицо подразделе- } \\
\text { ния }\end{array}$ & $\begin{array}{l}\text { бумажные носи- } \\
\text { тели }\end{array}$ \\
\hline 5 & $\begin{array}{l}\text { Формирование } \\
\text { первичного до- } \\
\text { кумента по учету } \\
\text { рисков }\end{array}$ & $\begin{array}{l}\text { ответственный } \\
\text { специалист со- } \\
\text { ответствующего } \\
\text { подразделения }\end{array}$ & $\begin{array}{l}\text { проект импортно- } \\
\text { го контракта }\end{array}$ & $\begin{array}{l}\text { эксперт, указан- } \\
\text { ный в листе согла- } \\
\text { сования }\end{array}$ & $\begin{array}{l}\text { бумажные носи- } \\
\text { тели }\end{array}$ \\
\hline 6 & $\begin{array}{l}\text { Отражение рисков } \\
\text { утраты и слу- } \\
\text { чайной гибели в } \\
\text { системе бухгалтер- } \\
\text { ского учета. }\end{array}$ & Бухгалтер & $\begin{array}{l}\text { Карточка учета } \\
\text { рисков. }\end{array}$ & $\begin{array}{l}\text { специалист ответ- } \\
\text { ственного подраз- } \\
\text { деления }\end{array}$ & $\begin{array}{l}\text { SAP, 1C Предпри- } \\
\text { ятие }\end{array}$ \\
\hline 7 & $\begin{array}{l}\text { Передача доку- } \\
\text { ментов на бумаж- } \\
\text { ных носителях } \\
\text { для дальнейшего } \\
\text { учета поступле- } \\
\text { ния МПЗ. Далее } \\
\text { при фактическом } \\
\text { поступлении им- } \\
\text { портных объектов } \\
\text { Кладовщик склада } \\
\text { закупок передает } \\
\text { первичные доку- } \\
\text { менты в бухгалте- } \\
\text { рию. }\end{array}$ & $\begin{array}{l}\text { Кладовщик склада } \\
\text { закупок }\end{array}$ & $\begin{array}{l}\text { Сопроводительные } \\
\text { документы (ТTH, } \\
\text { Тд, инвойс, между- } \\
\text { народная наклад- } \\
\text { ная CMR и др.). }\end{array}$ & $\begin{array}{l}\text { Экономист склада } \\
\text { закупок }\end{array}$ & $\begin{array}{l}\text { Бумажные носи- } \\
\text { тели }\end{array}$ \\
\hline 8 & $\begin{array}{l}\text { Отражение в } \\
\text { бухгалтерском } \\
\text { учете признания } \\
\text { импортного объ- } \\
\text { екта (при переходе } \\
\text { к организации эко- } \\
\text { номических выгод } \\
\text { и рисков). }\end{array}$ & Бухгалтер & $\begin{array}{l}\text { Первичные доку- } \\
\text { менты, карточка } \\
\text { по учету рисков, } \\
\text { служебная записка } \\
\text { от ответственного } \\
\text { подразделения. }\end{array}$ & $\begin{array}{l}\text { Кладовщик склада } \\
\text { закупок, специа- } \\
\text { лист ответственно- } \\
\text { го подразделения }\end{array}$ & $\begin{array}{l}\text { Бумажные носите- } \\
\text { ли, записи в систе- } \\
\text { ме (карточка учета } \\
\text { рисков, бухгал- } \\
\text { терские проводки } \\
\text { по начислению } \\
\text { резерва) }\end{array}$ \\
\hline
\end{tabular}


Таблица 3. Форма регламента по учету импортных объектов в части исходящей информации

\begin{tabular}{|c|c|c|c|c|c|}
\hline $\begin{array}{l}\text { № } \\
\Pi / \Pi\end{array}$ & $\begin{array}{c}\text { Наименование } \\
\text { функции и ее } \\
\text { содержание }\end{array}$ & $\begin{array}{c}\text { Ответственные за } \\
\text { исполнение }\end{array}$ & $\begin{array}{c}\text { Наименование } \\
\text { документа }\end{array}$ & От кого поступает & $\begin{array}{c}\text { Информационная } \\
\text { среда }\end{array}$ \\
\hline 1 & $\begin{array}{l}\text { Заключение им- } \\
\text { портного контрак- } \\
\text { та на закупку МПЗ }\end{array}$ & $\begin{array}{l}\text { проект импортно- } \\
\text { го контракта }\end{array}$ & экспертам & $\begin{array}{l}\text { бумажные носи- } \\
\text { тели }\end{array}$ & - \\
\hline 2 & $\begin{array}{l}\text { Согласование про- } \\
\text { екта импортного } \\
\text { Контракта }\end{array}$ & $\begin{array}{l}\text { проект импортно- } \\
\text { го контракта }\end{array}$ & экспертам & $\begin{array}{l}\text { бумажные носи- } \\
\text { тели }\end{array}$ & $\begin{array}{l}3 \text { рабочих дня с } \\
\text { момента получе- } \\
\text { ния проекта }\end{array}$ \\
\hline 3 & $\begin{array}{l}\text { Анализ проекта } \\
\text { импортного кон- } \\
\text { тракта, выявление } \\
\text { и оценка рисков, } \\
\text { присущих опера- } \\
\text { циям по данному } \\
\text { контракту }\end{array}$ & $\begin{array}{l}\text { проект импортно- } \\
\text { го контракта / лист } \\
\text { согласования }\end{array}$ & $\begin{array}{l}\text { эксперт в листе } \\
\text { согласования }\end{array}$ & $\begin{array}{l}\text { бумажные носи- } \\
\text { тели }\end{array}$ & $\begin{array}{l}3 \text { рабочих дня с } \\
\text { момента получе- } \\
\text { ния проекта }\end{array}$ \\
\hline 4 & $\begin{array}{l}\text { Анализ проекта } \\
\text { импортного кон- } \\
\text { тракта, выявление } \\
\text { и оценка рисков, } \\
\text { присущих опера- } \\
\text { циям по данному } \\
\text { контракту. }\end{array}$ & $\begin{array}{l}\text { проект импортно- } \\
\text { го контракта / лист } \\
\text { согласования }\end{array}$ & $\begin{array}{l}\text { эксперт, который } \\
\text { указан в листе } \\
\text { согласования }\end{array}$ & $\begin{array}{l}\text { бумажные носи- } \\
\text { тели }\end{array}$ & $\begin{array}{l}3 \text { рабочих дня с } \\
\text { момента получе- } \\
\text { ния проекта }\end{array}$ \\
\hline 5 & $\begin{array}{l}\text { Заполнение кар- } \\
\text { точки по учету } \\
\text { риска. }\end{array}$ & $\begin{array}{l}\text { карточка по учету } \\
\text { рисков }\end{array}$ & $\begin{array}{l}\text { информация } \\
\text { сохраняется в } \\
\text { системе (SAP, 1C } \\
\text { Предприятие) }\end{array}$ & $\begin{array}{l}\text { SAP, 1C Предпри- } \\
\text { ятие }\end{array}$ & $\begin{array}{l}\text { в день получения } \\
\text { листа согласования }\end{array}$ \\
\hline 6 & $\begin{array}{l}\text { Отражение рисков } \\
\text { утраты и слу- } \\
\text { чайной гибели в } \\
\text { системе бухгалтер- } \\
\text { ского учета. }\end{array}$ & $\begin{array}{l}\text { Записи в систе- } \\
\text { ме - формируются } \\
\text { бухгалтерские } \\
\text { проводки }\end{array}$ & $\begin{array}{l}\text { информация } \\
\text { сохраняется в } \\
\text { системе (SAP, 1C } \\
\text { Предприятие) }\end{array}$ & $\begin{array}{l}\text { SAP, 1C Предпри- } \\
\text { ятие }\end{array}$ & $\begin{array}{l}2 \text { рабочих дня с } \\
\text { момента получе- } \\
\text { ния карточки }\end{array}$ \\
\hline 7 & $\begin{array}{l}\text { Передача докумен- } \\
\text { тов на бумажных } \\
\text { носителях для } \\
\text { дальнейшего учета } \\
\text { поступления МПЗ. }\end{array}$ & $\begin{array}{l}\text { Инвойс Сопрово- } \\
\text { дит. документы } \\
\text { (TTH, ТД, СМR и } \\
\text { др.) Приходный } \\
\text { ордер }\end{array}$ & Бухгалтер & $\begin{array}{l}\text { Бумажные носи- } \\
\text { тели. Далее при } \\
\text { фактическом } \\
\text { поступлении им- } \\
\text { портных объектов } \\
\text { Кладовщик склада } \\
\text { закупок передает } \\
\text { первичные доку- } \\
\text { менты в бухгалте- } \\
\text { рию. }\end{array}$ & $\begin{array}{l}\text { В день получения } \\
\text { документов }\end{array}$ \\
\hline 8 & $\begin{array}{l}\text { Отражение в } \\
\text { бухгалтерском } \\
\text { учете признания } \\
\text { импортного объек- } \\
\text { та (при переходе к } \\
\text { организации эко- } \\
\text { номических выгод } \\
\text { и рисков). }\end{array}$ & $\begin{array}{l}\text { Записи в систе- } \\
\text { ме - формируются } \\
\text { бухгалтерские } \\
\text { проводки }\end{array}$ & $\begin{array}{l}\text { Хранится в систе- } \\
\text { ме }\end{array}$ & $\begin{array}{l}\text { SAP, 1C Предпри- } \\
\text { ятие }\end{array}$ & $\begin{array}{l}2 \text { рабочих дня с } \\
\text { момента получе- } \\
\text { ния карточки }\end{array}$ \\
\hline
\end{tabular}

Как видно из таблицы 2, на первый четырех этапах информация на счетах бухгалтерского учета не отражается. Начиная с пятого этапа происходит оценка рисков специалистом ответственного подразделения, инициирующего заключение импортного контракта на основании заполненного листа согласования. На этом этапе происходит ввод данных в систему о ри- сках, присущих данному контракту. На шестом этапе в случае если в карточке учета риска не указанно количественное выражение величины риска (или оценка риска не является достоверной), бухгалтер отражает информацию о рисках на забалансовом счете. На седьмом этапе бухгалтерские проводки не формируются. И накоенц, на псоледнем этапе происхлдит отражение 
в бухгалтерском учете записей. Такие как: Дт 10 (Атрибут «Импорт», Признак «по выбору») Кт 60 - отражается приход импортных материалов от поставщика и т.д. При этом сумма ранее созданного резерва списывается: Дт 91.1 Кт $91-$ списан ранее начисленный резерв (указывается пункт «дерева» проводок).

Структура регламентирующего стандарта предполагает следующие элементы:

- содержание функции;

- ответственные за исполнение;

- входящая и исходящая информация;

- информационная среда;

- срок предоставления.

Стандарты учета операций по импорту утверждаются в методической части, где будут определены способы оценки активов и обязательств организации в трех плоскостях учета: бухгалтерском, налоговом и управленческом, при этом для бухгалтерского учета данные способы оценки разрабатываются на основе профессионального суждения. Так же в данном разделе считаем необходимым приводить ссылки на карту проводок, где должны быть раскрыты все возможные корреспонденции счетов. Структура стандарта представлена в таблице 5 на примере учета основных средств приобретенных по импорту.
Структура методического стандарта учета операций по импорту предполагает внедрение следующих элементов:

- предмет и цель стандарта;

- нормативные документы;

- понятия, термины и сокращения;

- формы первичной документации;

- описание порядка учета.

Последний элемент методического стандарта может содержать не только теоретическое описание, но и дополнительно раскрывать элементы учетной политики на типовых примерах, а также детально описывать каждую корреспонденцию счетов ссылаясь на «дерево» проводок.

«Дерево» проводок в свою очередь представляет собой собрание бухгалтерских проводок, которые имеют место при импорте (табл. 5). Все корреспонденции счетов описаны в методическом стандарте, который ссылается не только на пункты регламента, регулирующего данный факт хозяйственной жизни, но и на раздел инструкции бухгалтера.

Взаимосвязь внутренних стандартов и регламентов представлена на рис. 3. Поручить разработку стандартов следует высококвалифицированными специалистами, предположительно сотрудникам отдела методологии бухгалтерского учета или внутреннего аудита. В связи с

Таблица 4. Форма «дерева» проводок

\begin{tabular}{|c|c|c|c|}
\hline \multirow{2}{*}{$\begin{array}{l}\text { No } \\
\Pi / \Pi\end{array}$} & \multicolumn{2}{|l|}{ Корреспонденция счетов } & \multirow{2}{*}{ Содержание фата хозяйственной жизни } \\
\hline & Дебет & Кредит & \\
\hline 1 & $\begin{array}{c}10 \\
\text { Атрибут «Импорт», } \\
\text { Признак «по выбору» }\end{array}$ & 60 & $\begin{array}{l}\text { Отражается поступление материалов по импорту от } \\
\text { поставщика (п.1.1. Регламента «Учет МПЗ», п. 1.1 Тех- } \\
\text { нологической инструкции бухгалтера по учету МПЗ) }\end{array}$ \\
\hline 2 & $\begin{array}{c}08 \\
\text { Атрибут «Импорт», } \\
\text { Признак «по выбору» }\end{array}$ & 60 & $\begin{array}{l}\text { Отражается поступление импортных внеоборотнных } \\
\text { активов от поставщика (п.1.1. Регламента «Учет ВА», } \\
\text { п. 1.1 Технологической инструкции бухгалтера по } \\
\text { учету ВА) }\end{array}$ \\
\hline 3 & $\begin{array}{c}41 \\
\text { Атрибут «Импорт», } \\
\text { Признак «по выбору» }\end{array}$ & 60 & $\begin{array}{l}\text { Отражается поступление импортных товаров от } \\
\text { поставщика (п.1.1. Регламента «Учет МПЗ», п. 1.1 Тех- } \\
\text { нологической инструкции бухгалтера по учету МПЗ) }\end{array}$ \\
\hline 4 & $\begin{array}{c}20 \\
\text { Атрибут «Импорт» }\end{array}$ & 60 & $\begin{array}{l}\text { Отражается поступление импортных услуг на себе- } \\
\text { стоимость продукции (п.1.1. Регламента «Учет МПЗ», } \\
\text { п. } 1.1 \text { Технологической инструкции бухгалтера) }\end{array}$ \\
\hline 5 & $\begin{array}{c}44 \\
\text { Атрибут «Импорт» }\end{array}$ & 60 & $\begin{array}{l}\text { Отражаются импортные услуги, связанные с про- } \\
\text { ведением выставки (п. Регламента «Учет МПЗ», п. } \\
\text { Технологической инструкции бухгалтера) }\end{array}$ \\
\hline 6 & 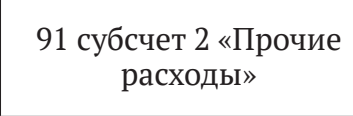 & 96 & $\begin{array}{l}\text { Начислен резерв по риску утраты в отчетном пери- } \\
\text { оде (п. Регламента «Учет МПЗ», п. Технологической } \\
\text { инструкции бухгалтера) }\end{array}$ \\
\hline 7 & 96 & 60,76 & $\begin{array}{l}\text { Отражается списание потерь за счет резерва в ре- } \\
\text { зультате повреждения товара (п. Регламента «Учет } \\
\text { МПЗ», п. Технологической инструкции бухгалтера) }\end{array}$ \\
\hline
\end{tabular}


Таблица 5. Структура стандарта по бухгалтерскому учету «Импорт основных средств»

\begin{tabular}{|c|c|}
\hline Структура стандарта & Содержание раздела \\
\hline \multicolumn{2}{|c|}{ 1. Общие положения } \\
\hline 1.1. Перечень нормативных, инструкций & $\begin{array}{l}\text { Перечисляются нормативные документы, регулиру- } \\
\text { ющие порядок учета }\end{array}$ \\
\hline $\begin{array}{l}\text { 1.2. Термины, определения, условные обозначения и } \\
\text { сокращения }\end{array}$ & $\begin{array}{l}\text { Раскрываются основные термины, даются определе- } \\
\text { ния, перечисляются сокращения }\end{array}$ \\
\hline 1.3. Критерии признания импортных объектов & $\begin{array}{l}\text { Раскрывается понятие контроля над объектом, пере- } \\
\text { ход рисков и экономических выгод }\end{array}$ \\
\hline \multicolumn{2}{|c|}{ 2. Учет импортных внеоборотных активов } \\
\hline 2.1. Оценка импортных внеоборотных активов & $\begin{array}{l}\text { Раскрывается порядок документооборота и приятые } \\
\text { в организации критерии оценки }\end{array}$ \\
\hline 2.3. Отражение на счетах бухгалтерского учета & $\begin{array}{l}\text { Перечисляются возможные корреспонденции счетов, } \\
\text { при отражении операций по импорту. Дается ссылка } \\
\text { на пункт Карты проводок. }\end{array}$ \\
\hline \multicolumn{2}{|c|}{ 3. Раскрытие информации в отчетности } \\
\hline $\begin{array}{l}\text { 3.1. Порядок исправления ошибок при отражении } \\
\text { импортных объектов }\end{array}$ & Раскрывается порядок исправления ошибок \\
\hline $\begin{array}{l}\text { 3.2. Раскрытие информации в финансовой отчетно- } \\
\text { сти и пояснениях к ней }\end{array}$ & $\begin{array}{l}\text { Раскрывается порядок принятия решений о раскры- } \\
\text { тии информации в финансовой отчетности или в } \\
\text { пояснениях }\end{array}$ \\
\hline $\begin{array}{l}\text { 3.3. Порядок отражения последствий изменения } \\
\text { учетной политики }\end{array}$ & $\begin{array}{l}\text { Раскрывается порядок последствий изменения учет- } \\
\text { ной политики }\end{array}$ \\
\hline
\end{tabular}

этим снижается риск возникновения ошибок в учете и соответственно риск искажения данных финансовой отчетности организаций. Ограничение возможных корреспонденций позволяет формировать единые алгоритмы не только самих форм отчетности, но и пояснений к ней, что особенно актуально для крупных компаний.

В технической части утверждаются должностные инструкции для бухгалтера. В каждой инструкции должна наблюдаться взаимосвязь между регламентом, методическими указаниями и «деревом» проводок.
Строить внутрифирменные стандарты и регламенты следует по принципу «от общего к частному», что позволит исключить дублирование функций, а также устранить противоречия с положениями федеральных стандартов. Для включения информации о рисках во все уровни стандартизации рекомендуем проанализировать риски, которым подвержена организация при осуществлении операций по импорту. Далее необходимо предпринять попытки оценки этих рисков с последующим отражением на счетах бухгалтерского учета в соответствии с «деревом»

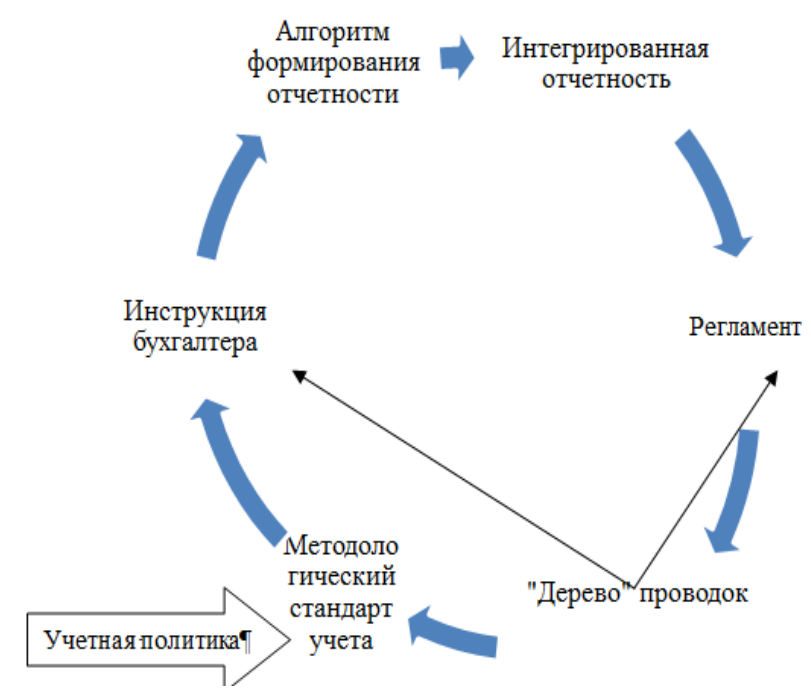

Рис. 3. Взаимосвязь стандартов и регламентов учетной системы 
проводок.

Один из ключевых факторов успеха внедрения стандартизации - это включение сотрудников в процесс разработки внутренних стандартов и регламентов, с целью совершенствования учета всех аспектов деятельности организации и повышения качества управления.

Обобщая все исследования, внедрение стандартизации учета операций по импорту необходимо осуществлять в несколько этапов:

1. Сбор информации. Это одна из основных стадий стандартизации, которая включает процедуры сбора, обработки и использования информации для формирования отчетных дан- ных, анализа и планирования деятельности.

2. Разработка регламента и методики.

3. Тестирование системы.

4. Проведение процедур по их актуализации. В случае изменения норма законодательства или бизнес-процессов в организации все внутренние стандарты должны быть также изменены.

Таким образом, реализация стандартов по учету операций по импорту на основе риск-ориентированного подхода, позволяют внедрить в организации целостный подход к их бухгалтерскому учету на основе профессионального суждения и отражению в финансовой отчетности.

\section{Библиографический список}

1. Бадюков, В. Ф. Оценка рисков: учеб. пособие / В. Ф.Бадюков. - Хабаровск: РИЦ ХГАЭП, 1998.

2. Бочарников, В.П.Прогнозные коммерческие расчеты и анализ рисков на Fuzzy for Excel / В. П. Бочарников, С. В. Свешников, С. И. Возняк.- СПб.: Алетейя, 2000

3. Вяткин, В. Н. Риск-менеджмент: учебник / В.Н. Вяткин, В. А. Гамза, Ю. Ю. Екатеринославский, Дж. Хэмптон; под ред. И. Юргенса.-М.: Дашков и Кㅇ 2003.-512 с.

4. Гамза, В.А. Рисковый спектр коммерческих организаций / В.А. Гамза, Ю.Ю.Екатеринославский.- М.: Экономика, 2002.- 108 с

5. Гитман, Л.Дж. Основы инвестирования / Л.Дж.Гитман, М.Д.Джонк; пер. с англ. О.Б. Буклемишева и др.; науч. ред. И. В.Ивашковская.-М: Дело, 1997.-192 с.

6. Глущенко, А.В.Стандартизация учета и ее роль в повышении надежности и прозрачности информации / А. В. Глущенко // Вестник ВолГУ.- 2003-2004.- Серия 3.- Вып. 8.- С. 75-78.

7. Дубров, А.М. Моделирование рисковых ситуаций в экономике и бизнесе / А.М.Дубров, Б.А.Лагоша, Е. Ю. Хрусталева, Т.П. Барановская. - 2-е изд., перераб. и доп.-М.: Финансы и статистика, 2001.-222 с.

8. Догиль, Л.Ф.Хозяйственный риск и финансовая устойчивость предприятий АПК: методологические и практические аспекты / Л. Ф. Догиль.-Минск: БГЭУ, 1999. - 240 с.

9. Кабышев, О.А. Предпринимательский риск: правовые вопросы: дис.... канд. юрид. наук / Кабышев О. А. - М., 1996. - 28 c.

10. Князевская, Н.В.Принятие рискованных решений в экономике и бизнесе / Н.В.Князевская, В.С. Князевский.- М.: Контур, 1998

11. Райзберг, Б. А. Основы бизнеса: учеб. пособие / Б.А.Райзберг.- М.: Ось-89, 1996. - 192 с.

12. Севрук, В. Т.Банковские риски / В. Т. Севрук.- М.: Дело Лтд, 1994.- 72 с.

13. Соколов, Я.В. Основы теории бухгалтерского учета / Я. В. Соколов. М.: Финансы и статистика, 2000.-496 с.

14. Тэпман, Л. Н. Риски в экономике: учеб. пособие для вузов / Л. Н. Тэпман; под ред. проф. В.А.Швандара.- М.: ЮНИТИ-ДАНА, 2002.- 380 с.

15. Уткин, Э. А. Управление рисками предприятия: учебно-практ. пособие / Э. А. Уткин, Д. А. Фролов.- М: ТЕИС, 2003. - $248 \mathrm{c}$.

16. Цветкова, Е. В.Риски в экономической деятельности: учеб. пособие / Е. В. Цветкова, И. О. Арлюкова.-СПб.: ИНВЭСЭП, Знание, 2002.- 64 с.

17. Шапкин, А.С.Экономические и финансовые риски. Оценка, управление, портфель инвестиций: монография / А. С. Шапкин.- М.: Дашков и К, 2003. - 544 с.

18. Шевелев, А.Е.Риски в бухгалтерском учете: учеб. пособие / А.Е.Шевелев, Е.В.Шевелева.- М.: КНОРУС, 2007.- 304 c. 